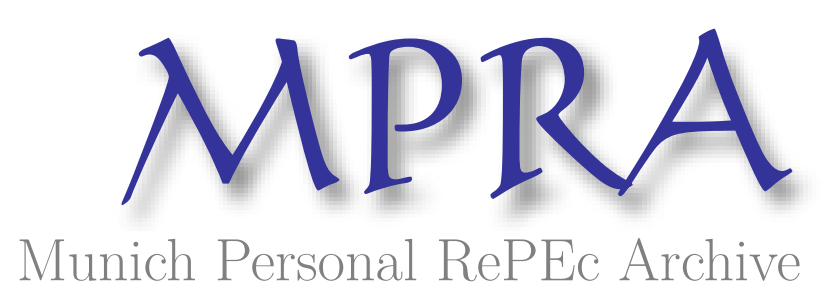

\title{
The effect of foreign aid on corruption: A quantile regression approach
}

\author{
Okada, Keisuke and Samreth, Sovannroeun \\ Graduate School of Economics, Kyoto University, Japan
}

8 January 2011

Online at https://mpra.ub.uni-muenchen.de/27969/

MPRA Paper No. 27969, posted 09 Jan 2011 19:34 UTC 


\title{
The Effect of Foreign Aid on Corruption: A Quantile Regression Approach*
}

\author{
Keisuke Okada ${ }^{\dagger}$ \\ Graduate School of Economics, Kyoto University, Japan \\ Sovannroeun Samreth \\ Japan Society for the Promotion of Science (JSPS) \\ Graduate School of Economics, Kyoto University, Japan
}

January 2011

\begin{abstract}
This paper investigates the effect of foreign aid on corruption using a quantile regression method. Our estimation results illustrate that foreign aid generally lessens corruption and, in particular, its reduction effect is larger in countries with low levels of corruption. In addition, considering foreign aid by donors, our analysis indicates that while multilateral aid has a larger reduction impact on corruption, bilateral aid from the world's leading donors, such as France, the United Kingdom, and the United States, has no significant effect on corruption. However, bilateral aid from Japan is shown to be statistically significant in lessening corruption.
\end{abstract}

Keywords: Foreign Aid; Corruption; Quantile Regression

JEL Classification: D73; F35

\section{Introduction}

Poverty reduction in developing countries has always been a great concern for international communities. Consequently, it is often a main theme addressed in many international arenas. Although fighting poverty requires various dimensions of policy prescriptions, foreign aid in both multilateral and bilateral forms from international institutions and donor countries is considered to be an important element contributing to poverty alleviation in developing countries.

\footnotetext{
${ }^{*}$ Samreth wishes to acknowledge the financial support from the Japan Society for the Promotion of Science (JSPS).

${ }^{\dagger}$ Corresponding author. Graduate School of Economics, Kyoto University, Yoshida-honmachi, Sakyo-ku, Kyoto 606-8501, Japan. E-mail: keisuke.okada.1125@gmail.com.
} 
In spite of its importance, foreign aid may also have impact on the quality of governance, particularly corruption, in the recipient countries. ${ }^{1}$ This impact has been examined in many studies, yielding mixed results. This is due to the fact that, in providing financial assistance, while donors often require that the recipient countries make commitments in reducing corruption, foreign aid also provides public officials with more room for rent-seeking behavior, consequently, leading to an aggravation in corruption in the recipient countries.

Svensson (2000) introduces a simple game-theoretic rent-seeking model and provides preliminary empirical evidence supporting the positive effect of foreign aid on corruption. Similarly, Knack (2001) provides evidence that higher level of aid may lead to an increase in corruption, by applying cross-country data. Alesina and Weder (2002) also suggest that foreign aid can have positive impacts on corruption. On the other hand, by pointing out that the evidence of Alesina and Weder (2002) is weak, Tavares (2003) empirically indicates that foreign aid reduces corruption.

Although they illustrate abundant evidence on the effect of foreign aid on corruption, the previous studies discussed above are primarily based on ordinary least squares (OLS) estimation, instrumental variables estimation, and panel analysis estimation. These approaches have disadvantages, as they only estimate the parameters of interest at the mean evaluation by a conditional distribution of the dependent variable (Billger and Goel, 2009). ${ }^{2}$ Unlike the previous studies, this paper contributes to the literature by investigating the effect of foreign aid on corruption in recipient countries using the quantile regression (QR) methodology developed by Koenker and Bassett (1978). The adoption of this method enables us to examine the effect of foreign aid on corruption at different intervals throughout the distribution of the dependent variable (corruption), providing us with better and more detailed information.

\section{Estimation methodology and data}

In order to examine the effect of foreign aid on corruption, we use the QR approach developed by Koenker and Bassett (1978) as the estimation methodology. We also report the OLS results for comparison purposes. The quantile estimator is obtained by solving the following optimization problem:

$$
\min _{\beta \in \mathbf{R}^{k}}\left[\sum_{i \in\left\{i: y_{i} \geq \mathbf{x}_{i}^{\prime} \beta\right\}} \theta\left|y_{i}-\mathbf{x}_{i}^{\prime} \beta\right|+\sum_{i \in\left\{i: y_{i}<\mathbf{x}_{i}^{\prime} \beta\right\}}(1-\theta)\left|y_{i}-\mathbf{x}_{i}^{\prime} \beta\right|\right],
$$

for the $\theta$ th quantile $(0<\theta<1)$, where $y_{i}$ is the dependent variable and $\mathbf{x}_{i}$ is $k$ by 1 vector of the explanatory variables. Using the $\mathrm{QR}$, we can qualify and quantify the impact of the

\footnotetext{
${ }^{1}$ The examination of the effect of foreign aid on other social and political elements besides corruption can be found in the previous studies, such as Djankov et al. (2008) for the effect on democracy, and Gomanee, Girma et al. (2005) and Gomanee, Morrissey et al. (2005) for the effect on the human development index (HDI) and infant mortality.

${ }^{2}$ Based on the quantile regression method, Billger and Goel (2009) examine the determinants of corruption. However, their study does not consider foreign aid.
} 
different explanatory variables at the different quantiles in the distribution of a dependent variable. The $\mathrm{QR}$ estimation is more robust than the OLS estimation with a presence of outliers and when the distribution of the dependent variable is a highly nonnormal pattern.

The data for the dependent variable, corruption, is released by the Worldwide Governance Indicators (WGI). The explanatory variable of most concern is foreign aid, defined as net disbursements of Official Development Assistance (ODA) divided by GDP. ${ }^{3}$ Following previous studies such as Serra (2006), other than foreign aid, we take into account economic, political, and cultural factors as the determinants of corruption.

For the economic factor, GDP per capita is considered, since it is shown to have a significant impact on corruption in most previous studies. The corruption level is expected to decrease with GDP per capita. For the political factor, democracy is taken into account, following Adserà et al. (2003), who suggest that corruption is reduced with higher levels of democracy. Finally, following La Porta et al. (1999) and Treisman (2000), for the cultural factor, British legal origin is incorporated into our estimation model. Countries that have adopted British legal origin tend to be less corrupt. A more detailed explanation of the data and descriptive statistics are reported in Table 1. The annual data from 120 developing countries over the period from 1995 to 2009 is employed for the estimation. We use five-year averages (1995 to 1999, 2000 to 2004 , and 2005 to 2009) for each variable to mitigate the short-term economic fluctuations.

[Table 1 here]

\section{Empirical results}

Table 2 presents the estimation results using a share of aggregate net disbursements of ODA to GDP as an aid variable. Robust standard errors for OLS estimates and QR results from the 10,000 bootstrapping repetitions are reported to obtain heteroskedasticity-robust estimates. The QR results in columns (2) to (6) illustrate that foreign aid generally has a reduction impact on corruption. In particular, its effect is larger in countries with lower levels of corruption. One possible explanation is that, during the time period from 1995 to 2009 in our sample, not only the donor institutions, such as the World Bank and the International Monetary Fund (IMF), but also major donor countries have paid more attention to government quality after the end of the Cold War. For explanatory variables other than foreign aid, the results show that they have the expected signs, which are consistent with those in previous studies. Economic development and democracy are important determinants reducing corruption. A difference between them is that while economic development diminishes corruption in all quantile levels and its impacts dwindle with the corruption level, democracy significantly reduces corruption in countries with a high level of corruption and its reduction impact increases with the corruption level. In addition, cultural factors from the United Kingdom

\footnotetext{
${ }^{3}$ Since net disbursements of ODA are used, we delete the observations with negative values. However, even if we include these observations, we still obtain similar results.
} 
(British legal origin) have a reduction influence on corruption.

[Table 2 here]

Table 3 shows the estimation results when we replace aggregate aid with multilateral and bilateral aid from four major donor countries: France, Japan, the United Kingdom (UK), and the United States (US). The specification is the same as in Table 2. We only report the results of aid variables to save space. For explanatory variables other than foreign aid, the estimation results are similar to those in Table 2 in terms of signs and significances.

In Panel A, where multilateral aid from the aid institutions such as the World Bank, the IMF, and regional development banks are used, a reduction impact of multilateral aid is found to be larger than that of total foreign aid. This result may be attributed to the fact that the donor institutions normally require that recipient countries make corruption reduction commitments a condition to provide financial assistance. The aid from international institutions tends to focus on altruistic purposes, rather than strategic ones, compared to bilateral aid donors.

In Panels B to E, bilateral aid from France, Japan, the UK, and the US are used. Except for Japan, bilateral aid from these major donor countries generally has no significant impact on corruption. Bilateral aid is often related to strategic purposes between donor and recipient countries and to historical relationships, such as former colonies. Therefore, donor countries may not care much about institutional quality. Bilateral aid from Japan has a significant reduction effect on corruption, partly because relationships with former colony countries are not as close as those in the other three countries investigated in this study.

[Table 3 here]

Finally, as a robustness check, we also conduct the same analysis using another corruption index, the Corruption Perceptions Index, released by Transparency International. We obtain similar results, although we do not report the estimation results. ${ }^{4}$

\section{Conclusion}

This paper examines the effect of foreign aid on corruption using quantile regression analysis. Our estimation results show that foreign aid generally decreases the corruption level and, in particular, its reduction effect is larger in countries with low levels of corruption. In addition, analyzing the effects of foreign aid by donors indicates that while multilateral aid has a larger reduction impact on corruption, except for Japan, bilateral aid from the world's leading donor countries, including France, the UK, and the US, has no significant effect.

The results from our study provide some policy implications. Although foreign aid is considered an important element to reduce poverty, since foreign aid may increase the op-

\footnotetext{
${ }^{4}$ The detailed results can be provided from the authors upon request.
} 
portunities of rent-seeking behaviors, careful attention should be paid to its side effect. Our estimation results suggest that donors should be more prudent when they provide aid to countries with higher levels of corruption. Multilateral aid implementation should be encouraged rather than bilateral aid.

\section{References}

[1] Adserà A., Boix, C., Payne, M., 2003. Are you being served? political accountability and quality of government. Journal of Law, Economics, and Organization, 19, 445-490.

[2] Alesina, A., Weder, B., 2002. Do corrupt governments receive less foreign aid? American Economic Review 92, 1126-1137.

[3] Billger, S. M., Goel, R. K., 2009. Do existing corruption levels matter in controlling corruption? cross-country quantile regression estimates. Journal of Development Economics 90, 299-305.

[4] Djankov, S., Montalvo, J. G., Reynal-Querol, M., 2008. The curse of aid. Journal of Economic Growth 13, 169-194.

[5] Gomanee, K., Girma, S., Morrissey, O., 2005. Aid, public spending and human welfare: evidence from quantile regressions. Journal of International Development 17, 299-309.

[6] Gomanee, K., Morrissey, O., Mosley, P., Verschoor, A., 2005. Aid, government expenditure, and aggregate welfare. World Development 33, 355-370.

[7] Knack, S., 2001. Aid dependence and the quality of governance: cross-country empirical tests. Southern Economic Journal 68, 310-329.

[8] Koenker, R., Bassett Jr., G., 1978. Regression quantiles. Econometrica 46, 33-50.

[9] La Porta, R., Lopez-de-Silanes, F., Shleifer, A., Vishny, R., 1999. The quality of government. Journal of Law, Economics, and Organization, 15, 222-279.

[10] Serra, D., 2006. Empirical determinants of corruption: a sensitivity analysis. Public Choice 126, 225-256.

[11] Svensson, J., 2000. Foreign aid and rent-seeking. Journal of International Economics 51, $437-461$.

[12] Tavares, J., 2003. Does foreign aid corrupt? Economics Letters 79, 99-106.

[13] Treisman, D., 2000. The causes of corruption: a cross-national study. Journal of Public Economics 76, 399-457. 
Table 1: Data description

\begin{tabular}{|c|c|c|c|c|c|}
\hline Variable & Description and source & Mean & Std. Dev. & Max. & Min. \\
\hline Corruption & $\begin{array}{l}\text { Control of corruption. The variable is rescaled so that a larger value } \\
\text { indicates more corruption. Note that the WGI provides the data for } \\
\text { the years of } 1996,1998,2000 \text {, and each year from } 2002 \text { to } 2008 \text {. } \\
\text { Source: Worldwide Governance Indicators. }\end{array}$ & 3.5057 & 0.6383 & 0.8529 & 5.1949 \\
\hline Log GDP per capita & $\begin{array}{l}\text { GDP per capita is the real Gross Domestic Product per capita at } \\
\text { the purchasing power parity in } 2005 \text { international dollars. } \\
\text { Source: World Development Indicators (online). }\end{array}$ & 7.9139 & 1.0894 & 5.2220 & 10.7350 \\
\hline Democracy & $\begin{array}{l}\text { This is a democracy index reflecting the competitiveness of political } \\
\text { participation, the openness and competitiveness of executive recruitment, } \\
\text { and the constraints on the chief executive. Source: Polity IV Project. }\end{array}$ & 1.7447 & 6.0681 & -10 & 10 \\
\hline British legal origin & $\begin{array}{l}\text { Dummy variables for legal systems whose origin is Anglo-Saxon } \\
\text { Common Law. Other than British legal origin, La Porta et al. (1999) } \\
\text { categorized legal origin into French Civil Law, German Civil Law, } \\
\text { Socialist Law, and Scandinavian Law. Source: La Porta et al. (1999). }\end{array}$ & 0.2943 & 0.4564 & 0 & 1 \\
\hline Aid/GDP (total) & $\begin{array}{l}\text { This ratio is the share between aggregate net official development } \\
\text { assistance disbursed in current U.S. dollars and GDP in current U.S. } \\
\text { dollars. It includes grants and loans undertaken by the official sector with } \\
\text { the promotion of economic development and welfare as the main objective } \\
\text { at concessional financial terms, where loans have a grant element of at } \\
\text { least } 25 \% \text {. } \\
\text { Sources: OECD DAC and World Development Indicators (online). }\end{array}$ & 0.0691 & 0.0911 & 0.00008246 & 0.6782 \\
\hline Aid/GDP (multilateral) & $\begin{array}{l}\text { Multilateral aid includes aid from the World Bank, as well as the regional } \\
\text { development banks. } \\
\text { Source: OECD DAC and World Development Indicators (online). }\end{array}$ & 0.0282 & 0.0410 & 0.00000314 & 0.2906 \\
\hline Aid/GDP (France) & $\begin{array}{l}\text { It includes aid flows from France. } \\
\text { Sources: OECD DAC and World Development Indicators (online). }\end{array}$ & 0.0057 & 0.0118 & 0.00000166 & 0.0853 \\
\hline Aid/GDP (Japan) & $\begin{array}{l}\text { It includes aid flows from Japan. } \\
\text { Sources: OECD DAC and World Development Indicators (online). }\end{array}$ & 0.0056 & 0.0095 & 0.00000146 & 0.0888 \\
\hline Aid/GDP (UK) & $\begin{array}{l}\text { It includes aid flows from the United Kingdom. } \\
\text { Sources: OECD DAC and World Development Indicators (online). }\end{array}$ & 0.0036 & 0.0086 & 0.00000015 & 0.0680 \\
\hline Aid/GDP (US) & $\begin{array}{l}\text { It includes aid flows from the United States. } \\
\text { Sources: OECD DAC and World Development Indicators (online). }\end{array}$ & 0.0089 & 0.0167 & 0.00000046 & 0.1937 \\
\hline
\end{tabular}

Note: The values for each variable are based on the average values of 5-year average for the period 1995-2009. 
Table 2: Corruption and foreign aid

Dependent variable: Corruption

\begin{tabular}{lllllll}
\hline \hline & $(1)$ & $(2)$ & $(3)$ & $(4)$ & $(5)$ & $(6)$ \\
& OLS & Q 0.10 & Q 0.25 & Q 0.50 & Q 0.75 & Q 0.90 \\
\hline Log GDP per capita & $-0.3595^{* * *}$ & $-0.5829^{* * *}$ & $-0.4438^{* * *}$ & $-0.2894^{* * *}$ & $-0.2538^{* * *}$ & $-0.2629^{* * *}$ \\
& $(0.0434)$ & $(0.0711)$ & $(0.0641)$ & $(0.0487)$ & $(0.0470)$ & $(0.0589)$ \\
Democracy & $-0.0187^{* * *}$ & -0.0034 & -0.0138 & $-0.0190^{* * *}$ & $-0.0254^{* * *}$ & $-0.0309^{* * *}$ \\
& $(0.0054)$ & $(0.0105)$ & $(0.0093)$ & $(0.0067)$ & $(0.0060)$ & $(0.0061)$ \\
British legal origin & $-0.2567^{* * *}$ & $-0.1995^{*}$ & $-0.2221^{* *}$ & $-0.2855^{* * *}$ & $-0.2104^{* * *}$ & $-0.1685^{* *}$ \\
& $(0.0621)$ & $(0.1175)$ & $(0.1031)$ & $(0.0833)$ & $(0.0729)$ & $(0.0737)$ \\
Aid (Total) & $-1.2738^{* * *}$ & $-3.2700^{* * *}$ & $-2.1376^{* *}$ & -0.4729 & $-0.7568^{*}$ & $-0.9903^{*}$ \\
& $(0.4850)$ & $(1.0535)$ & $(1.0394)$ & $(0.5902)$ & $(0.4152)$ & $(0.5655)$ \\
Constant & $6.5467^{* * *}$ & $7.6936^{* * *}$ & $6.9014^{* * *}$ & $6.0373^{* * *}$ & $6.0691^{* * *}$ & $6.3280^{* * *}$ \\
& $(0.3583)$ & $(0.5940)$ & $(0.5314)$ & $(0.4083)$ & $(0.3840)$ & $(0.4986)$ \\
\hline Countries & 120 & 120 & 120 & 120 & 120 & 120 \\
Observations & 333 & 333 & 333 & 333 & 333 & 333 \\
\hline
\end{tabular}

Notes:

1. The asterisks $* * *, * *$, and $*$ are $1 \%, 5 \%$, and $10 \%$ of significant levels, respectively.

2. The numbers in parentheses are heteroskedasticity-robust standard errors.

3. Quantile regression results are based on the 10,000 bootstrapping repetitions. 
Table 3: Corruption and foreign aid by donors

Dependent variable: Corruption

\begin{tabular}{|c|c|c|c|c|c|c|}
\hline & (1) & $(2)$ & (3) & (4) & (5) & (6) \\
\hline & OLS & Q 0.10 & Q 0.25 & Q 0.50 & Q 0.75 & Q 0.90 \\
\hline \multicolumn{7}{|l|}{ Panel A } \\
\hline \multirow[t]{2}{*}{ Aid (multilateral) } & $-2.7721^{* *}$ & $-7.4934^{* * *}$ & $-5.8832^{* * *}$ & -1.8937 & $-1.7069^{*}$ & $-2.3729^{*}$ \\
\hline & $(1.1063)$ & $(2.4579)$ & $(2.1855)$ & $(1.4144)$ & $(0.9440)$ & $(1.2758)$ \\
\hline Countries & 120 & 120 & 120 & 120 & 120 & 120 \\
\hline Observations & 334 & 334 & 334 & 334 & 334 & 334 \\
\hline \multicolumn{7}{|l|}{ Panel B } \\
\hline \multirow[t]{2}{*}{ Aid (France) } & $-5.5808^{* *}$ & -8.1767 & -8.9816 & -5.4291 & $-6.5979 * *$ & -2.8715 \\
\hline & $(2.6697)$ & $(6.1325)$ & $(7.7073)$ & $(4.5842)$ & $(2.7478)$ & $(3.0540)$ \\
\hline Countries & 121 & 121 & 121 & 121 & 121 & 121 \\
\hline Observations & 318 & 318 & 318 & 318 & 318 & 318 \\
\hline \multicolumn{7}{|l|}{ Panel C } \\
\hline \multirow[t]{2}{*}{ Aid (Japan) } & $-10.2452^{* * *}$ & -12.2498 & -8.8271 & $-8.0802^{* *}$ & $-10.5882^{* * *}$ & $-11.9499 * * *$ \\
\hline & $(2.4751)$ & $(8.8953)$ & $(6.2596)$ & $(3.3199)$ & $(2.2032)$ & $(2.2649)$ \\
\hline Countries & 119 & 119 & 119 & 119 & 119 & 119 \\
\hline Observations & 313 & 313 & 313 & 313 & 313 & 313 \\
\hline \multicolumn{7}{|l|}{ Panel D } \\
\hline \multirow[t]{2}{*}{ Aid (UK) } & 0.1812 & 4.0243 & -0.6823 & 2.2479 & -1.2418 & -2.6240 \\
\hline & $(2.8212)$ & $(6.7583)$ & $(6.1481)$ & $(3.4527)$ & $(4.3712)$ & $(3.9863)$ \\
\hline Countries & 117 & 117 & 117 & 117 & 117 & 117 \\
\hline Observations & 297 & 297 & 297 & 297 & 297 & 297 \\
\hline \multicolumn{7}{|l|}{ Panel E } \\
\hline \multirow[t]{2}{*}{ Aid (US) } & -0.5652 & $-9.8700^{*}$ & -2.9726 & 1.6077 & 3.4041 & 1.2663 \\
\hline & $(1.9316)$ & $(5.8145)$ & $(7.0495)$ & $(3.2097)$ & $(2.1076)$ & $(2.6011)$ \\
\hline Countries & 112 & 112 & 112 & 112 & 112 & 112 \\
\hline Observations & 298 & 298 & 298 & 298 & 298 & 298 \\
\hline
\end{tabular}

Notes:

1. The asterisks $* * *, * *$, and $*$ are $1 \%, 5 \%$, and $10 \%$ of significant levels, respectively.

2. The numbers in parentheses are heteroskedasticity-robust standard errors.

3. Quantile regression results are based on the 10,000 bootstrapping repetitions.

4. Although, as in Table 2, the natural logarithm of GDP per capita, democracy, British legal origin, and a constant term are included as explanatory variables, the results are not reported. 